УдК: [796.035:796.015.13]-055.2

ISSN (Ukrainian ed. Print) 1991-0177 ISSN (Ukrainian ed. Online) 1999-818X 2020, No 6(80), C.58-64 doi: $10.15391 /$ snsv.2020-6.009

\title{
Побудова комплексної програми оздоровчого тренування для жінок першого періоду зрілого віку
}

\author{
Галина Артем'єва \\ Ірина Латвинська \\ Тетяна Мошенська
}

Харківська державна академія фізичної культури, Харків, Україна

\begin{abstract}
Мета: визначити ефективність побудови комплексної програми оздоровчого тренування для жінок першого періоду зрілого віку.

Матеріал і методи: дослідження тривало протягом 2019-2020 навчального року на базі фітнес-клубу «Територія Fitness». За однорідністю ознак були сформовані дві групи жінок першого періоду зрілого віку - контрольна (КГ) та експериментальна (ЕГ), по 13 осіб у кожній. Нами застосовувались сучасні методи дослідження: теоретичний аналіз і узагальнення літературних джерел, педагогічне спостереження, педагогічний експеримент, педагогічне тестування, медико-біологічні методи, методи математичної статистики.

Результати: у процесі проведення експериментального дослідження нами було побудовано програму оздоровчого тренування. Програма враховувала розподіл фізичного навантаження в залежності від завдань кожного періоду, етапу, мезо і мікроциклу.

Висновки: комплексна програма оздоровчого тренування довела свою ефективність. У ході експерименту спостерігалися міжгрупові достовірні зміни соматометричних та функціональних показників жінок першого періоду зрілого віку при $p<0,05$ та фізичної підготовленості при $p<0,05, p<0,01, p<0,001$. Приріст соматометричних показників та показників функціонального стану організму жінок ЕГ складає 4,7\% - 17, 3 \%. У той час у жінок КГ діапазон змін цих показників коливається у межах від 0,4 \% до 12,2 \%. У показниках фізичної підготовленості також спостерігається більш значний їх приріст у жінок ЕГ, а діапазон складає проміжок від 14 \% до 45, 8 \%. У жінок КГ приріст показників фізичної підготовленості знаходиться у межах 7\% - 24\%.
\end{abstract}

Ключові слова: оздоровче тренування, жінки першого періоду зрілого віку.

\section{Вступ}

За ствердженням джерел масової інформації на сьогоднішній день в Україні простежується негативна тенденція зміни показників тривалості життя та стану здоров'я населення. Погіршується демографічна ситуація, яка веде до зниження економічної та соціальної складової існування суспільства $[6,10]$.

Отже, одним з пріоритетних завдань, яке потребує вирішення, на сьогодні $є$ створення умов для підвищення рівня здоров'я та благополуччя населення держави.

Здоров'я за визначенням ВООЗ - це стан повного фізичного, духовного і соціального благополуччя, а не тільки відсутність хвороб і фізичних дефектів [3].

У 2016 році наказом президента України була затверджена Національна стратегія з оздоровчої рухової активності в Україні на період до 2025 року «Рухова активність - здоровий спосіб життя - здорова нація» (далі - Стратегія). Основним завданням Стратегії є підвищення рівня залучення різних верств населення до оздоровчої рухової активності, яка у подальшому допоможе вирішити економічні, соціальні та гуманітарні питання не лише особи, а суспільства в цілому $[4,13]$.
Науково доведено, що рухова активність людини у перший період зрілого віку є запорукою здоров'я на усе подальше життя. Залучення людей до здорового способу життя сприяє покращенню його якості, забезпечує гармонійний розвиток та є одним з дієвих чинників профілактики захворювань [2, 16].

Як вказують О. В. Андрєєва (2014), В. М. Завійська (2015), особливу увагу слід приділяти збереженню та покращенню здоров'я жінок першого періоду зрілого віку, адже завдяки їм можна подолати демографічну кризу. Цей вік для жінки $є$ найкращим для народження здорового потомства $[1,5]$.

3 народженням дитини та їі доглядом у перші роки у жінки змінюється гормональний фон, зменшується різнобічна рухова активність, зростає фізична, психічна, емоційна втома, що призводить до зниження показників здоров'я. При цьому, як відмічає Т. О. Синиця (2015), динаміка погіршення показників здоров'я жінок першого періоду зрілого віку носить зворотній, функціональний характер, а знизити такі негативні наслідки можна шляхом оптимізації рухового режиму на заняттях фітнесом.

Автори О. Я. Кібальник, О. А. Томенко (2010), О. В. Андрєєва (2014), В. Кашуба, Н. Гончарова, М. Дудко, О. Мартинюк (2016) також підкреслюють, що заняття оздоровчим 
фітнесом позитивно впливають на динаміку покращення фізичного стану жінок першого періоду зрілого віку.

Порушуючи питання розвитку програм оздоровчого тренування треба відмітити, що застосування комплексного підходу при їх побудові дає змогу вирішити одразу декілька оздоровчих завдань. Однак, формування таких програм повинно відбуватися на глибокому розумінні тих фізіологічних змін, які відбуваються в організмі людини саме під впливом конкретних засобів [1].

Аналіз науково-методичної літератури довів присутність достатньої кількості досліджень, які стосуються питань визначення ефективності занять з жінками першого періоду зрілого віку за певною методикою. Значно менше приділяється уваги застосуванню комплексних програм оздоровчого тренування з цим контингентом.

Отже, на сьогодні існує запит у розширенні теоретичної та методичної бази, яка б давала можливість обирати жінкам ефективні комплексні оздоровчі програми, а фітнес-тренерам грамотно поєднувати необхідні методики, застосовувати певні засоби та визначати їх дозування при вирішенні педагогічних завдань в оздоровчому тренуванні з досліджуваним контингентом.

Мета дослідження - визначити ефективність побудови комплексної програми оздоровчого тренування для жінок першого періоду зрілого віку.

Зв'язок дослідження 3 науковими чи практичними завданнями, планами, програмами. Наукова робота виконана відповідно до ініціативної наукової теми кафедри гімнастики, танцювальних видів спорту та хореографії: «Теоретико-методологічні засади розвитку системоутворюючих компонентів фізичної культури (спорт, фітнес і рекреація) на 2020-2025 рр.), номер державної реєстрації 0120U101215».

\section{Матеріал і методи дослідження}

Педагогічний експеримент проводився на базі фітнес-клубу «Територія Fitness». Дослідження тривало протягом 2019-2020 навчального року. За однорідністю ознак були сформовані дві групи жінок першого періоду зрілого віку - контрольна (КГ) та експериментальна (ЕГ), по 13 осіб у кожній. Нами застосовувались сучасні методи дослідження: теоретичний аналіз і узагальнення літературних джерел, педагогічне спостереження, педагогічний експеримент, педагогічне тестування, медикобіологічні методи, методи математичної статистики.

\section{Результати дослідження}

На першому етапі побудови комплексної програми оздоровчого тренування нами були визначені соматометричні показники, показники функціонального стану та працездатності організму жінок, показники їх фізичної підготовленості. 3 урахуванням рекомендацій фахівців з оздоровчого тренування $[8,11,15,17]$, результатів контролю досліджуваних показників та досвіду практичної роботи нами були визначені параметри оздоровчого тренування.

Для досягнення поставленої мети нами були поєднані засоби наступних програм: стретчинг, протокол Tabata, MФP, TRX, глайдінг, різновиди аеробіки, фітбол, силові класи аеробної спрямованості. Засоби тренування поділялися наступним чином: за анатомічною озна- кою (тобто яка група м'язів буде основною, залученою до роботи); за характером - статичні та динамічні; з використанням предметів та обладнання (гантелі, бодібари, фітболи, степ-платформи, тощо) [7].

При побудові оздоровчого тренування застосовувались: а) загальнотеоретичні методи, спрямовані на оволодіння знаннями; б) практичні методи, які передбачають оволодіння руховими вміннями, навичками та розвиток фізичних якостей $[7,12]$.

У процесі проведення тренувань нами використовувались такі види контролю: а) оперативний, який передбачає оцінку оперативних станів - термінових реакцій організму на навантаження (одразу після тренування, або безпосередньо при виконанні вправи); б) поточний, що спрямований на оцінку поточного стану жінок (протягом малих циклів тренувань); в) етапний, який дозволяє підбити підсумки тренувань за визначений час (етап, період) [2, 9].

При розробці плану занять протягом річного циклу оздоровчого тренування ми спиралися на підхід авторів С. В. Синиці, Л. Є. Шестерової (2010), які виділяють у річному циклі двохциклову модель оздоровчого тренування і поділяють весь рік на: осіннє-зимовий та веснянолітній етапи [12]. Отже, ми зробили розподіл тренувань протягом двох етапів. У кожному етапі згідно відомостей Т.Ю. Круцевич (2003), ми виділили по три періоди: підготовчий, основний та підтримуючий [7]. У кожному періоді було визначено середні цикли оздоровчого тренування - мезоцикли: втягуючі, набуття фізичної форми, підтримання фізичної форми та активного відпочинку. у різних мезоциклах були поставлені завдання та запланована спрямованість тренувань.

Кожен мезоцикл складався з малих циклів - мікроциклів тривалістю 7 днів. За мікроцикл проводилось 3 аеробні тренування кардіо та силової спрямованості, тривалістю 60 хвилин кожне та інтенсивністю 50-75\% від МПК. Інші чотири дні був запланований відпочинок. Таке планування занять дає змогу організму відновитися після навантаження та завдяки адаптації вийти на новий рівень функціонування [2, 14].

Адаптаційні процеси - це функціональні, структурні перебудови організму, які підвищують його працездатність і дозволяють функціонувати в певних умовах. При систематичних тренуваннях ці механізми удосконалюються. Усі ці перебудови діють на різних рівнях організації організму: на рівні клітини (підвищується швидкість внутрішніх реакцій, швидкість і здатність утилізації продуктів розпаду, опір клітини до кислотного середовища); на рівні органу (підвищується ефективність його роботи); на рівні системи (поліпшується робота кардіореспіраторної, гормональної, м'язової систем і т. д.); на рівні організму в цілому (підвищується обсяг роботи, яку може виконати організм) $[8,18]$.

Відсоткове співвідношення засобів оздоровчого тренування на осіннє-зимовому етапі втягуючого мезоциклу складало: 30\% - вправи на розтягування та відновлення (стретчінг, МФР); 35\% - вправи на розвиток кардіо-респіраторної системи (різновиди бігу, стрибків, елементи аеробіки тощо), 35\% - силові вправи (з власною вагою, фітбол, бодібари). Таке відсоткове співвідношення було обрано тому, що даний етап розрахований на поступову підготовку організму жінок першого періоду зрілого віку до основного навантаження. 


\section{СЛОБОЖАНСЬКИЙ НАУКОВО-СПОРТИВНИЙ ВІСНИК}

На етапі набуття фізичної форми співвідношення засобів становило: 25\% - вправи на розтягування та відновлення (стретчинг в підготовчій та заключній частин тренування); 35\% - вправи на розвиток кардіо-респіраторної системи (інтенсивні вправи для виведення ЧСС в цільову зону (степ-аеробіка, танцювальна аеробіка)); $40 \%$ - силові вправи (з обтяженням, з власною вагою (глайдінг, ТРХ, гантелі, бодібари)).

На етапі підтримання фізичної форми відсоткове співвідношення становило: 20\% - вправи на розтягування та відновлення (вправи стретчингу, МФР); 40\% - вправи на розвиток кардіо-респіраторної системи - (на степ-платформі, стрибки та їх різновиди); 40\% - силові вправи - з обтяженням, з подоланням опору, з суміжних напрямків оздоровчого фітнесу (TPX, глайдінг, футбол, протокол Tabata).

У період активного відпочинку з кінця грудня до середини січня заняття у фітнес-клубі чергувалися з рекреаційними засобами і були спрямовані на відновлення організму жінок. Відсоткове співвідношення засобів складало: 15\% - вправи на розтягування та відновлення (стретчинг та МФР); 60\% - вправи на розвиток кардіореспіраторної системи - застосовувались засоби фітнесу та рекреації (піші прогулянки, їзда на ковзанах тощо); $25 \%$ - силові вправи з обтяженням та вправи з фітболом.

Співвідношення засобів оздоровчого тренування на весняно-літньому етапі втягуючого мезоциклу складало: 25\% - вправи на розтягування та відновлення (стретчинг); 40\% - вправи на розвиток кардіо-респіраторної системи (різновиди бігу, стрибків, елементи базової аеробіки тощо), 35\% - силові вправи (з власною вагою, глайдінг, фітбол, протокол Tabata). Таке відсоткове співвідношення засобів було запропоновано тому, що даний етап розрахований на поступову адаптацію організму жінок до навантаження.

На етапі набуття фізичної форми співвідношення засобів становило: $15 \%$ - вправи на розтягування та відновлення (стретчинг в підготовчій та заключній частині тренування); 40\% - вправи на розвиток кардіо-респіраторної системи (інтенсивні вправи танцювальної та степ-аеробіка, бігу для виведення ЧСС в цільову зону); 45\% - силові вправи (з обтяженням, з власною вагою, 3 фітболом, глайдінг, протокол Tabata, TPX). Обране відсоткове співвідношення розраховувалось на набуття рельєфу м'язів та більш «атлетичної форми тіла».

На етапі підтримання фізичної форми у I мезоциклі співвідношення засобів становило: 20\% - вправи на розтягування та відновлення (стретчинг, пілатес та МФР); 45\% - вправи на розвиток кардіо-респіраторної системи (стрибки зі скакалкою та з суміжних напрямків фітнесу); 35\% - силові вправи (з гантелями, бодібарами, з власною вагою, з фітболом, глайдінг).

На етапі підтримання фізичної форми у II мезоциклі співвідношення засобів становило: 15\% - вправи на розтягування та відновлення (стретчинг, пілатес та МФР); 50\% - вправи на розвиток кардіо-респіраторної системи (інтенсивні вправи аеробіки, біг для виведення та утримання ЧСС в цільовій зоні); 35\% - силові вправи (з обтяженням, з власною вагою, TRX, протокол Tabata). Обране відсоткове співвідношення I та II мезоциклу підтримання фізичної форми розраховувалось на зменшення прошарку жирової тканини.

У мезоциклі активного відпочинку заняття у фітнесклубі чергувалися з рекреаційними засобами.
Характерною особливістю зміни відсоткового співвідношення засобів фітнесу протягом річного циклу оздоровчого тренування була закономірність реакцій організму на навантаження, швидкість протікання адаптаційних процесів та становлення фізичної форми.

Оцінка ефективності запропонованих організаційно-методичних умов побудови комплексної програми оздоровчого тренування та міри впливу засобів на досліджувані показники жінок першого періоду зрілого віку проводилась після контрольного тестування та аналізу вихідних та контрольних даних. Результати порівняльного аналізу показників представлені у табл. 1 і 2.

При порівнянні внутрішньогрупових соматометричних показників жінок КГ відмічається їх позитивна динаміка, але достовірних змін при $p<0,05$ не відбулось. У жінок ЕГ також відмічається позитивна динаміка покращення досліджуваних показників, однак, на відміну від показників КГ в ЕГ достовірно при $\mathrm{p}<0,001$ змінилися показники ОГК, ОТ та ОС (табл. 1).

Протягом педагогічного експерименту відмічається позитивна динаміка змін внутрішньогрупових показників функціонального стану та працездатності організму жінок КГ та ЕГ. Однак, слід відмітити, що у жінок КГ достовірно при $\mathrm{p}<0,01$ змінились результати у тесті ІГСТ, а ужінок ЕГ достовірно при $\mathrm{p}<0,001$ змінились результати у тесті ІГСТ та при $p<0,05$ змінились результати у тесті Ортостатична проба (табл. 1).

При порівнянні міжгрупових показників жінок КГ та ЕГ на достовірність змін слід відмітити, що достовірно при $\mathrm{p}<0,05$ змінились соматометричні показники: ОТ (tрозр $=2,48)$ та ОC (tрозр $=2,78)$ і показники функціонального стану та працездатності: Ортостатична проба $($ tрозр $=2,48)$ та ICT (tрозр =2,26) (табл. 1). Інші показники залишились без достовірних змін.

Аналізуючи дані табл. 2 можна сказати, що у КГ жінок протягом педагогічного експерименту спостерігається позитивна динаміка змін показників фізичної підготовленості. Внутрішньогрупові достовірні зміни при $p<0,05$ відбулись у показниках силової витривалості у тестах: жим штанги 15 кг лежачи від грудей та присід зі штангою 10 кг та при р<0,01 у тесті піднімання тулуба в сід із положення лежачи.

Внутрішньогрупові показники фізичної підготовленості у ЕГ жінок змінились більш суттєво. Відбулись достовірні при $p<0,001$ зміни показників сили у тесті динамометрія кисті (права, ліва); у показниках силової витривалості; у наступних тестах: жим штанги 15 кг лежачи від грудей, присід зі штангою 10 кг, піднімання тулуба в сід з положення лежачи, згинання та розгинання рук в упорі лежачи з колін, планка; у показнику відносної сили у силовому індексі, показнику гнучкості у тесті нахил тулуба вперед з положення сидячи.

Протягом педагогічного експерименту відбулись міжгрупові достовірні зміни у досліджуваних показниках жінок першого періоду зрілого віку КГ та ЕГ. При р<0,05 достовірно змінились показники сили у тесті динамометрія правої (tрозр $=2,38)$ та лівої кисті (tрозр $=2,38)$. При $\mathrm{p}<0,01$ відбулись достовірні зміни у силовому індексі (tрозр $=3,46)$, показниках силової витривалості у тестах: жим штанги 15 кг лежачи (tрозр =3,83), присід зі штангою 10 кг на плечах (tрозр =4,2); показнику рухливості суглобів у тесті нахил тулуба вперед з положення сидячи $($ tрозр $=3.83)$ При $\mathrm{p}<0,001$ достовірними $€$ зміни у показ-
Артем'єва, Г., Латвинська, І., Мошенська, Т. (2020), «Побудова комплексної програми оздоровчого тренування для жінок першого періоду зрілого віку»
Слобожанський науково-спортивний вісник, № 6(80), С. 58-64, doi:10.15391/snsv.2020-6.009 
Таблиця 1

Порівняння соматометричних та функціональних показників жінок першого періоду зрілого віку у КГ та ЕГ протягом педагогічного експерименту, (n=26)

\begin{tabular}{|c|c|c|c|c|c|c|c|}
\hline \multirow{2}{*}{\multicolumn{2}{|c|}{ Показники }} & \multicolumn{2}{|c|}{$\begin{array}{c}\text { Контрольна } \\
(\mathrm{n}=13)\end{array}$} & \multicolumn{2}{|c|}{$\begin{array}{l}\text { Експериментальна } \\
\text { (n=13) }\end{array}$} & \multirow{2}{*}{$\mathrm{t}$} & \multirow{2}{*}{$\mathrm{P}$} \\
\hline & & $\bar{X}_{ \pm \mathrm{m}}$ & $\begin{array}{c}\text { Приріст, } \\
\text { \% }\end{array}$ & $\bar{X}_{ \pm \mathrm{m}}$ & $\begin{array}{c}\text { Приріст, } \\
\%\end{array}$ & & \\
\hline \multicolumn{2}{|l|}{ Вік } & $25,08 \pm 0,4$ & - & $25,46 \pm 0,43$ & - & - & $>0,05$ \\
\hline \multicolumn{2}{|c|}{ Довжина тіла, см } & $166,62 \pm 1,53$ & - & $164,62 \pm 1,05$ & - & - & $>0,05$ \\
\hline \multirow{2}{*}{ Maca, кг } & $\mathrm{B}$ & $63,62 \pm 1,76$ & \multirow{2}{*}{1,4} & $64,92 \pm 1,51$ & \multirow{2}{*}{5,5} & \multirow{2}{*}{0,8} & \multirow{2}{*}{$>0,05$} \\
\hline & K & $62,7 \pm 1,58$ & & $61,38 \pm 1,07$ & & & \\
\hline \multirow{2}{*}{ ОГК, см } & $\mathrm{B}$ & $89,77 \pm 6,19$ & \multirow{2}{*}{2,2} & $92,15 \pm 1,32$ & \multirow{2}{*}{7,9} & \multirow{2}{*}{1,76} & \multirow{2}{*}{$>0,05$} \\
\hline & K & $87,77 \pm 1,43$ & & $84,85 \pm 1,32^{* * *}$ & & & \\
\hline \multirow{2}{*}{ OT, см } & $\mathrm{B}$ & $72,54 \pm 1,57$ & \multirow{2}{*}{0,4} & $75,69 \pm 1,6$ & \multirow{2}{*}{10,6} & \multirow{2}{*}{2,48} & \multirow{2}{*}{$<0,05$} \\
\hline & $\mathrm{K}$ & $72,85 \pm 2,6$ & & $67,69 \pm 1,98^{* * *}$ & & & \\
\hline \multirow[t]{2}{*}{$\mathrm{OC}, \mathrm{cm}$} & B & $97,77 \pm 1,49$ & \multirow[t]{2}{*}{3,5} & $95,92 \pm 0,9$ & \multirow[t]{2}{*}{6,2} & \multirow[t]{2}{*}{2,78} & \multirow[t]{2}{*}{$<0,05$} \\
\hline & K & $94,38 \pm 1,54$ & & $90 \pm 0,94^{* * *}$ & & & \\
\hline \multirow{2}{*}{ ОП, см } & $\mathrm{B}$ & $30,69 \pm 0,31$ & \multirow{2}{*}{1,0} & $31,31 \pm 1,48$ & \multirow{2}{*}{4,7} & \multirow{2}{*}{0,78} & \multirow{2}{*}{$>0,05$} \\
\hline & K & $30,38 \pm 0,29$ & & $29,85 \pm 0,19$ & & & \\
\hline \multirow{2}{*}{$\begin{array}{c}\text { Ортостатична проба, } \\
\text { уд/хв. }\end{array}$} & $\mathrm{B}$ & $19,77 \pm 0,99$ & \multirow{2}{*}{12,2} & $17,77 \pm 0,96$ & \multirow{2}{*}{17,3} & \multirow{2}{*}{2,15} & \\
\hline & K & $17,35 \pm 1,1$ & & $14,7 \pm 1,05^{*}$ & & & $<0,05$ \\
\hline ІГСТ Ум ол & $\mathrm{B}$ & $63,93 \pm 0,56$ & 75 & $63,84 \pm 0,1$ & 12 & 226 & $<005$ \\
\hline 11С1, ум.од & K & $69,1 \pm 1,09^{* *}$ & 1,5 & $72,6 \pm 1,3^{* * *}$ & 12 & 2,20 & $<0,05$ \\
\hline
\end{tabular}

Примітка: В - вихідні дані; К - контрольні дані; зірочками відмічені внутрішньогрупові достовірні зміни: *- достовірність відмін при р<0,05; **- достовірність відмін при $p<0,01$; ***- достовірні зміни при $p<0,001$

Таблиця 2

Порівняння показників фізичної підготовленості жінок першого періоду зрілого віку у КГ та ЕГ протягом педагогічного експерименту, $(n=26)$

\begin{tabular}{|c|c|c|c|c|c|c|c|}
\hline \multirow{2}{*}{\multicolumn{2}{|c|}{ Тести }} & \multicolumn{2}{|c|}{ Контрольна (n=13) } & \multicolumn{2}{|c|}{$\begin{array}{c}\text { Експериментальна } \\
(\mathrm{n}=13)\end{array}$} & \multirow{2}{*}{$\mathrm{t}$} & \multirow{2}{*}{$\mathrm{P}$} \\
\hline & & $\bar{X}_{ \pm \mathrm{m}}$ & $\begin{array}{c}\text { Приріст, } \\
\text { \% }\end{array}$ & $\bar{X}_{ \pm \mathrm{m}}$ & $\begin{array}{c}\text { Приріст, } \\
\text { \% }\end{array}$ & & \\
\hline \multirow{4}{*}{ Кистьова динамометрія, кг } & права & $22,85 \pm 0,7$ & \multirow{2}{*}{7,5} & $23,62 \pm 0,7$ & 14 & \multirow{2}{*}{2,38} & \multirow{2}{*}{$<\mathbf{0 , 0 5}$} \\
\hline & права & $24,7 \pm 0,88$ & & $27,5 \pm 0,5^{* * *}$ & 14 & & \\
\hline & ліва & $21,23 \pm 0,8$ & \multirow{2}{*}{7} & $22,31 \pm 0,6$ & \multirow{2}{*}{14,5} & \multirow{2}{*}{2,38} & \multirow{2}{*}{$<0,05$} \\
\hline & ліва & $22,85 \pm 0,8$ & & $26,1 \pm 0,5^{* * *}$ & & & \\
\hline \multirow{2}{*}{ Силовий індекс, \% } & $\mathrm{B}$ & $36,25 \pm 1,4$ & \multirow{2}{*}{9,1} & $37,1 \pm 1,36$ & \multirow{2}{*}{18,5} & \multirow{2}{*}{3,46} & \multirow{2}{*}{$<\mathbf{0 , 0 1}$} \\
\hline & $\mathrm{K}$ & $39,8 \pm 1,6$ & & $45,5 \pm 1,1^{* * *}$ & & & \\
\hline \multirow{2}{*}{ Тест Купера, км } & $\mathrm{B}$ & $2,3 \pm 0,08$ & \multirow{2}{*}{8,3} & $2,38 \pm 0,07$ & \multirow{2}{*}{15,6} & \multirow{2}{*}{0,85} & \multirow{2}{*}{$>0,05$} \\
\hline & K & $2,51 \pm 0,06$ & & $2,82 \pm 0,07$ & & & \\
\hline \multirow{2}{*}{ Проба Ромберга, с } & $\mathrm{B}$ & $7,15 \pm 0,45$ & \multirow{2}{*}{14} & $7,76 \pm 0,44$ & \multirow{2}{*}{18} & \multirow{2}{*}{1,24} & \multirow{2}{*}{$>0,05$} \\
\hline & $\mathrm{K}$ & $8,3 \pm 0,43$ & & $9,46 \pm 0,43$ & & & \\
\hline \multirow{2}{*}{$\begin{array}{l}\text { Жим штанги (15кг) лежачи } \\
\text { від груді, разів }\end{array}$} & $\mathrm{B}$ & $8,23 \pm 0,56$ & \multirow{2}{*}{22} & $7,92 \pm 0,51$ & \multirow{2}{*}{45,8} & \multirow{2}{*}{3,83} & \multirow{2}{*}{$<\mathbf{0 , 0 1}$} \\
\hline & K & $10,54 \pm 0,5^{*}$ & & $14,6 \pm 0,6^{* * *}$ & & & \\
\hline & $\mathrm{B}$ & $9,77 \pm 0,71$ & 22 & $10 \pm 0,58$ & 43 & & \\
\hline ра3 & $\mathrm{K}$ & $12,54 \pm 0,7^{*}$ & 22 & $17,5 \pm 0,7^{* * *}$ & 43 & 4,2 & $<\mathbf{0 , 0 1}$ \\
\hline Піднімання тулуба в сід із & $\mathrm{B}$ & $14,15 \pm 0,7$ & & $14,54 \pm 0,5$ & & & \\
\hline положення лежачи, разів & K & $18,6 \pm 0,8^{* *}$ & 24 & $25,7 \pm 0,5^{* * *}$ & 43,2 & 6,24 & $<0,001$ \\
\hline Згинання розгинання рук в & $\mathrm{B}$ & $9 \pm 0,64$ & 22 & $9,85 \pm 0,48$ & 437 & 53 & $<0001$ \\
\hline упорі лежачи з колін, разів & K & $11,46 \pm 0,7$ & 22 & $17,5 \pm 0,6^{* * *}$ & 45,1 & , & $<0,001$ \\
\hline Пганга с & $\mathrm{B}$ & $39,85 \pm 2,7$ & 10 & $43,54 \pm 2,05$ & 213 & 478 & $<0001$ \\
\hline Планка, с & $\mathrm{K}$ & $44,31 \pm 2,9$ & 10 & $55,3 \pm 2,4^{* * *}$ & 21,3 & 4,18 & $<0,001$ \\
\hline Нахил тулуба з положення & $\mathrm{B}$ & $8 \pm 0,45$ & 16 & $8,38 \pm 0,54$ & 375 & 383 & $<0.01$ \\
\hline сидячи, см & $\mathrm{K}$ & $9,54 \pm 0,46$ & 10 & $13,4 \pm 0,6^{* * *}$ & $3 /, 3$ & 5,03 & $<0,01$ \\
\hline
\end{tabular}

Примітка: В - вихідні дані; К - контрольні дані; зірочками відмічені внутрішньогрупові достовірні зміни: *- достовірність зміни при $p<0,05 ;$ **- достовірні зміни при $p<0,01$; ***- достовірні зміни при $p<0,001$ 


\section{СЛОБОЖАНСЬКИЙ НАУКОВО-СПОРТИВНИЙ ВІСНИК}

никах силової витривалості у тестах: піднімання тулуба в сід 3 положення лежачи (tрозр $=6,24)$, згинання розгинання рук в упорі лежачи 3 колін (tрозр $=5,3)$, планка (

\section{Висновки / Дискусія}

Оздоровчий ефект фізичних вправ спостерігається лише тоді, коли вони раціонально збалансовані за спрямованістю, обсягом і потужністю відповідно до індивідуальних можливостей тих, хто займається. Такі ж положення відображені у роботах А.С. Купцова, Т.Б. Кукоби, В.П. Шульпина, Т.О. Синиці.

Також мають вплив на кінцевий результат і теоретичні положення при побудові різних програм. У визначенні основних принципів оздоровчого тренування наші погляди співпадають з думкою визнаних фахівців в області оздоровчого тренування: Т.С. Лисицької, Л.В. Сидневої, С.В. Синиці, Л.Є. Шестерової.

Протягом педагогічного експерименту простежується позитивна динаміка змін досліджуваних показників КГ та ЕГ жінок першого періоду зрілого віку, що вказує на ефективність впливу засобів оздоровчого тренування. Однак, представлений розподіл навантаження та його планування у середніх та малих циклах протягом річного циклу оздоровчого тренування з жінками першого періоду зрілого віку за експериментальною програмою має більш суттєвий вплив на організми жінок.

Протягом педагогічного експерименту приріст соматометричних показників та показників функціонального стану організму жінок ЕГ складає 4,7\% - 17,3\%. У той час у жінок КГ діапазон цих показників коливається у межах від 0,4\% до 12,2\%. У показниках фізичної підготовленості також спостерігається більш значний їх приріст у жінок ЕГ, а діапазон складає проміжок від 14\% до 45,8\%. У жінок КГ приріст показників фізичної підготовленості знаходиться у межах 7\% - 24\%.

Отже, комплексна програма оздоровчого тренування довела свою ефективність та може бути запропонованою для використання у оздоровчому тренуванні жінок першого періоду зрілого віку.

Перспективи подальших досліджень планується визначити вплив комплексної програми оздоровчого тренування на організми жінок другого періоду зрілого віку.

Конфлікт інтересів. Автори заявляють, що немає конфлікту інтересів, який може сприйматись таким, що завдасть шкоди неупередженості статті.

Джерела фінансування. Ця стаття не отримала фінансової підтримки від державної, громадської або комерційної організації.

\section{Список посилань}

1. Андрєєва О. В. (2014), “Концептуальні основи рекреаційно-оздоровчої діяльності різних груп населення”, Молодіжний науковий вісник, Вип. 16, С. 7-13.

2. Беляк Ю., Грибовська І., Музика Ф. (2018), Теоретико-методичні основи оздоровчого фітнесу: навчальний посібник. Львів, 208 с.

3. Всесвітня Організація охорони здоров'я. URL: https://www.who.int/ru/about/who-we-are/constitution (дата звернення 05.11.2020)

4. Дутчак М. В., Василенко М. М. (2013), "Теоретичне обґрунтування кваліфікаційної характеристики фітнес-тренера", Педагогіка, психологія і медико-біологічні проблеми фізичного виховання і спорту, №2, С. 17-21.

5. Завійська В.М.(2015), “Дослідження ефективності занять шейпінгом жінок першого періоду зрілого віку”, Молода спортивна наука України, Т. 4, С. 35-39.

6. Кашуба В., Гончарова Н., Дудко М., Мартинюк О. (2016), “До питання підвищення ефективності фізкультурно-оздоровчих занять різних груп населення", Молодіжний науковий вісник, Вип. 24, С. 9-14.

7. Круцевич Т. Ю. (2003), Основы общей теории физического воспитания. Ч.2. Киев: Олимпийская литература, 291 с.

8. Купцов А. С., Кукоба Т. Б., Шульпина В. П. (2011), "Влияние различных средств фитнес-тренировки на показатели физического развития и силовые способности женщин 25-35 лет”, Омский научный вестник, № 6, С. 23 - 28.

9. Лисицкая Т. С. Сиднева Л. В. (2002), Аэробика: Теория и методика. Т1. М: ФАР, 221 с.

10. Прилуцька Т. А., Ткачова А. І. (2018), "Сучасні тенденції програмування занять оздоровчим фітнесом жінок зрілого віку", Перспективи, проблеми та наявні здобутки розвитку фізичної культури і спорту в Україні: матеріали I Всеукраїнської інтернет-конференції "COLOR OF SCIENCE", 29-30 січня, С.90-94.

11. Синиця Т. О. (2017), "Оптимізація рухової активності жінок зрілого віку засобами оздоровчої аеробіки", Матеріали 69-ї наук. конф. професорів, викладачів, наукових працівників, аспірантів та студентів університету. Полтава: ПолтНТУ, Т. 3, С. 252-254.

12. Синиця С. В., Шестерова Л. Є. (2010), Оздоровча аеробіка. Спортивно-педагогічне вдосконалення: навчальний посібник. Полтава: ПолтНТУ, 244 с.

13. Чеховська Л. Ю., Жданова О. М. (2016), “Проблеми організаційно-методичних основ фітнесу в системі масового спорту (спорту для всіх)”, Фізична активність, здоров’я і спорт, №4 (26), С. 67-75.

14. Edwards S. (2002), «Physical Exercise and Psychological Wellness», International Journal of Mental Health Promotion, vol. 4(2), pp. 40-46.

15. Glassman G. What Is Fitness and Who Is Fit? (URL: https://crossfitthreshold.wordpress.com/what-is-fitness-and-who-is-fit/) (дата звернення 03.11.2020)

16. Le Corre E. The History of Physical Fitness (URL: http://www.artofmanliness.com/2014/09/24/the-history-of-physicalfitness/) (дата звернення 07.11.2020)

17. Orlick T. (2008), In pursuit of excellence. 4-th ed. Champaign: Human Kinetics, VIII, 312 p.

Артем'єва, Г., Латвинська, І., Мошенська, Т. (2020), «Побудова комплексної програми оздоровчого тренування для жінок першого періоду зрілого віку" 
18. Podrigalo L.V., Artemieva H.P., Rovnaya O.A., Misevra N. S. et al. (2019), «Features of physical development and somatotype of girls and women involved in fitness», Pedagogiks psychology and medical-biological problems of physical training and sports, № 23 (4): pp.182-188.

Стаття надійшла до редакції: 04.12.2020 p.

Опубліковано: 21.12.2020 p.

Аннотация. Галина Артемьева, Ирина Латвинская, Татьяна Мошенская. Построение комплексной программы оздоровительной тренировки для женщин первого периода зрелого возраста. Цель: определить эффективность построения комплексной программы оздоровительной тренировки для женщин первого периода зрелого возраста. Материал и методы: исследование продолжалось в течение 2019-2020 учебного года на базе фитнес-клуба «Teppитория Fitness». По однородности признаков были сформированы две группы женщин первого периода зрелого возраста - контрольная (КГ) и экспериментальная (ЭГ), по 13 человек в каждой. Нами применялись современные методы исследования: теоретический анализ и обобщение литературных источников, педагогическое наблюдение, педагогический эксперимент, педагогическое тестирование, медико-биологические методы, методы математической статистики. Результаты: в процессе проведения экспериментального исследования нами была построена программа оздоровительной тренировки. Программа учитывала распределение физической нагрузки в зависимости от задач каждого периода, этапа, мезо и микроцикла. Выводы: комплексная программа оздоровительной тренировки доказала свою эффективность. В ходе эксперимента наблюдались межгрупповые достоверные изменения соматометрических и функциональных показателей женщин первого периода зрелого возраста при $p<0,05$ и физической подготовленности при $p<0,05, p<0,01, p<0,001$. Прирост соматометрических показателей и показателей функционального состояния организма женщин ЭГ составляет 4,7\% - 17,3\%. В то время у женщин КГ диапазон изменений этих показателей колеблется в пределах от 0,4\% до 12,2\%. В показателях физической подготовленности также наблюдается более значительный их прирост у женщин ЭГ, а диапазон составляет промежуток от 14\% до 45, 8\%. У женщин КГ прирост показателей физической подготовленности находится в пределах 7\% - 24\%.

Ключевые слова: оздоровительная тренировка, женщины первого периода зрелого возраста.

Abstract. Galyna Artemyeva, Iryna Latvynska, Tetiana Moshenska. Construction a comprehensive health training program for women in the first period of adulthood. Purpose: to determine the effectiveness of building a comprehensive program of health training for women of the first period of adulthood. Material and methods: the research lasted during the 2019-2020 academic year on the basis of the fitness club "Territory Fitness". According to the homogeneitic indicators, two groups of women of the first period of adulthood - control (CG) and experimental (EG) were formed, 13 people in each group. Modern research methods were used: theoretical analysis and synthesis of literary sources, pedagogical observation, pedagogical experiment, pedagogical testing, medical and biological methods, methods of mathematical statistics. Results: in the process of conducting an experimental study, the program of health training was constructed. The program took into account the distribution of physical load depending on the tasks of each period, stage, meso and microcycle. Conclusions: during the experiment, significant intergroup changes in the somatometric and functional indicators of women of the first period of adulthood were observe at $p<0.05$ and physical fitness at $p<0.05$, at $p<0.01$, at $p$ $<0.001$. The increase in somatometric indicators and indicators of the functional state of the body of women EG is $4.7 \%-17.3 \%$. At the same time, in women with CG, the range of changes in these indicators ranges from $0.4 \%$ to $12.2 \%$. In terms of physical preparedness, there is also a more significant their increase in women with EG, and the range is from $14 \%$ to $45.8 \%$. In women with CG, the increase in physical preparedness is in the range of $7 \%-24 \%$.

Keywords: health training, women of the first period of adulthood.

\section{References}

1. Andrieieva, O. V. (2014), "Conceptual bases of recreational and health-improving activity of different groups of the population», Molodizhnyi naukovyi visnyk. Vyp. 16, pp. 7-13. (in Ukr.)

2. Beliak, Yu., Hrybovska, I., Muzyka, F. (2018), Teoretyko-metodychni osnovy ozdorovchoho fitnesu [Theoretical and methodological foundations of health fitness]: navchalnyi posibnyk, Lviv, 208 p. (in Ukr.)

3. Vsesvitnia Orhanizatsiia okhorony zdorovia. URL: https://www.who.int/ru/about/who-we-are/constitution (date of accessed 05.11.2020).

4. Dutchak, M. V., Vasylenko, M. M. (2013), "Theoretical substantiation of the qualification characteristic of a fitness trainer», Pedahohika, psykholohiia i medyko-biolohichni problemy fizychnoho vykhovannia i sportu, No. 2, pp. 17-21. (in Ukr.)

5. Zaviiska, V. M. (2015), «Study of the effectiveness of shaping women of the first period of adulthood», Moloda sportyvna nauka Ukrainy. T. 4, pp. 35-39. (in Ukr.)

6. Kashuba, V., Honcharova, N., Dudko, M., Martyniuk, O. (2016), "On the issue of increasing the effectiveness of physical culture and health classes of different groups of the population", Molodizhnyi naukovyi visnyk, Vyp.24, pp. 9-14. (in Ukr.)

7. Krutcevich, T.Yu. (2003), Osnovy obshchei teorii fizicheskogo vospitaniia [Foundations of the general theory of physical education]. Ch.2. K: Olimpiiskaia literatura, 291 p. (in Russ.)

8. Kuptcov, A.S., Kukoba, T.B., Shulpina, V.P. (2011), «The influence of various means of fitness training on the indicators of physical development and strength abilities of women 25-35 years old», Omskii nauchnyi vestnik, No. 6, pp. 23 - 28 (in Russ.)

9. Lisitckaia, T.S., Sidneva, L.V. (2002), Aerobika: Teoriia i metodika [Aerobics: Theory and Methodology]. T1. M: FAR, 221 p. (in Russ.)

10. Prylutska, T.A., Tkachova, A.I. (2018), «Current trends in the programming of health fitness classes for mature women», Perspektyvy, problemy ta naiavni zdobutky rozvytku fizychnoi kultury i sportu v Ukraini: materialy I Vseukrainska internet-konferentsiia «COLOR OF SCIENCE». 29-30 sichnia, pp. 90-94. (in Ukr.) 


\section{СЛОБОЖАНСЬКИЙ НАУКОВО-СПОРТИВНИЙ ВІСНИК}

11. Synytsia, T. O. (2017), «Optimization of motor activity of mature women by means of health aerobics», Materialy 69-yi nauk. konf. profesoriv, vykladachiv, naukovykh pratsivnykiv, aspirantiv ta studentiv universytetu. Poltava: PoltNTU. T. 3, pp. 252-254. (in Ukr.)

12. Synytsia, S. V., Shesterova, L. Ye. (2010), Ozdorovcha aerobika. Sportyvno-pedahohichne vdoskonalennia [Sports and pedagogical improvement]: navchalnyi posibnyk. Poltava: PoltNTU, 244 p. (in Ukr.)

13. Chekhovska, L. Yu., Zhdanova, O. M. (2016), «Problems of organizational and methodical bases of fitness in the system of mass sports (sports for all)», Fizychna aktyvnist, zdorovia i sport, No. 4 (26), pp. 67-75. (in Ukr.)

14. Edwards, S. (2002), «Physical Exercise and Psychological Wellness», International Journal of Mental Health Promotion, vol. 4(2), pp. 40-46. (in Eng.)

15. Glassman, G. What Is Fitness and Who Is Fit? (URL: https://crossfitthreshold.wordpress.com/what-is-fitness-and-who-is-fit/) (date of accessed 03.11.2020) (in Eng.)

16. Le Corre E. The History of Physical Fitness (URL: http://www.artofmanliness.com/2014/09/24/the-history-of-physicalfitness/) (date of accessed 07.11.2020) (in Eng.)

17. Orlick, T. (2008), In pursuit of excellence. 4-th ed. Champaign: Human Kinetics. VIII, 312 p. (in Eng.)

18. Podrigalo, L.V., Artemieva, H.P., Rovnaya, O.A., Misevra, N. S. et al. (2019), «Features of physical development and somatotype of girls and women involved in fitness", Pedagogiks psychology and medical-biological problems of physical training and sports, 04: No. 23 (4) pp.182-188. (in Eng.)

Received: 04.12.2020.

Published: 21.12.2020.

\section{Відомості про авторів / Information about the Authors}

Артем'єва Галина Павлівна: к.фіз.вих., доцент; Харківська державна академія фізичної культури: вул. Клочківська 99, м. Харків, 61058, Україна.

Артемьева Галина Павловна: к.физ.восп., доцент; Харьковская государственная академия физической культуры: ул. Клочковская 99, г. Харьков, 61058, Украина.

Galyna Artemyeva: PhD (Physical Education and Sport), Associate Professor; Kharkiv State Academy of Physical Culture: Klochkivska 99, Kharkiv, 61058, Ukraine.
ORCID.ORG/0000-0002-6965-4972
E-mail: galina9767@gmail.com

Латвинська Ірина Сергіївна: Харківська державна академія фізичної культури: вул. Клочківська 99, м. Харків, 61058, Україна.

Латвинская Ирина Сергеевна: Харьковская государственная академия физической культуры: ул. Клочковская 99, г. Харьков, 61058, Украина.

Iryna Latvynska: Kharkov State Academy of Physical Culture: Klochkivska 99, Kharkiv, 61058, Ukraine.

ORCID.ORG/0000-0003-4482-7790

E-mail: irina.latvinskay@gmail.com

Мошенська Тетяна Валеріївна: Харківська державна академія фізичної культури: вул. Клочківська 99, м. Харків, 61058, україна.

Мошенская Татьяна Валерьевна: Харьковская государственная академия физической культуры: ул. Клочковская 99, г. Харьков, 61058, Украина.

Tetiana Moshenska: Kharkov State Academy of Physical Culture: Klochkivska 99, Kharkiv, 61058, Ukraine.

ORCID.ORG/0000-0002-0771-5717

E-mail: tvmoshenska@gmail.com 